\title{
A DESCRIPTIVE STUDY ON THE USE OF CODE MIXING BY THE ENGLISH TEACHER AT SMAN BALI MANDARA IN THE ACADEMIC YEAR 2014/2015
}

\author{
N. M. G. Purnamasari, I. N. A. J. Putra, N. K. A. Suwastini. \\ Jurusan Pendidikan Bahasa Inggris \\ Universitas Pendidikan Ganesha \\ Singaraja, Indonesia \\ Email: \{ginawijaya09@gmail.com, ajp undiksha@yahoo.com, \\ ariesuwastini80@gmail.com\}@undiksha.ac.id
}

\begin{abstract}
This study aimed at finding out the process of code mixing, the reasons of using code mixing by English teacher of grade $X$ and knowing the students' responses on the use of code mixing used by their English teacher at SMAN Bali Mandara in the academic year 2014/2015. This research was conducted by using descriptive qualitative design. The instruments used in this study were observation sheet, audio recorder, interview guide and questionnaires. Accordingly, the data accumulation showed that there was 84 sentences $(62.22 \%)$ classified as insertion processes, and then 37 sentences $(27.41 \%)$ belonged to alternation process, and the last there were 14 sentences (10.37\%) classified as congruent lexicalization processes. The reasons of using code mixing were, (1) to make intention of clarifying the speech content for interlocutor, (2) to be emphatic about something, (3) there is no appropriate word which can be understood by the students, (4) to help the teacher to create relax situation, and (5) to quote somebody else. The students' responses were, (1) code mixing is able to facilitate the students in some aspects such as the content of English material, vocabulary mastery, and grammar mastery, and (2) code mixing is able to negotiate social rules in some aspects such as make the relationship between teacher and students become less formal in terms of teaching-learning process, and increase communicative interaction between teacher and the students. Based on the result, it is suggested for the English teacher to use code mixing in the teaching and learning process in order to reach a better understanding of the students.
\end{abstract}

Key words: code mixing, English teaching-learning process

\section{INTRODUCTION}

The globalization era gives big impact to humans' communication. To be able to communicate and maintain relationship with people from other countries, they should be able to speak more than one language. Thus, it is not surprising if someone can master not only his/her mother tongue, but also second language and foreign language. This condition is called bilingualism or multingualism.
According to Jendra (2010:68), bilingualism is an aptitude of using more than one language equally. The person who is involved called bilingual, means that she or he has an ability to speak in two languages or more and has the knowledge about both the grammar and the vocabulary in his/her mind.

Bilingualism is closely interrelated to the terms called code switching and code mixing. Code switching is the use of more 
than one language by switching from one language to another (Jendra, 2012:73). According to Myers-Scotton (1993) in Hermi (2003), there are three types of code switching, namely; intra-sentential code switching, inter-sentential code switching and interpersonal code switching. Meanwhile, code mixing which is also called as intra-sentential code switching, is the use of two languages together when the speakers change from one language to the other in the course of a single utterance (Wardaugh, 2002:107). The use of intrasentential code mixing is a sign of lack of English proficiency (Weinreich,1953: 73 in Muysken, 2001: 1). According to Muysken (2001:1), the term intra-sentential code mixing is prefer to use rather than intrasentential code switching in order to refer to all cases where lexical items and grammatical features from two languages appear in one sentence. As what would be achieved through this study which concerns with code mixing in a sentence, so code mixing is used as its term. Thus, it can be defined that code mixing is the use of two languages together which only involve the use of phrases or group of words and clause in the course of single utterance.

Code mixing is the use of two languages together when the speakers change from one language to the other in the course of a single utterance (Wardaugh, 2002:107). One of the reasons using code mixing is that it helps people to understand the target language by mixing with their native language (Sumarsih et.al, 2014:77). Consequently, Indonesian people, especially students, learn English through Bahasa Indonesia. It is because, in the learning process, Indonesian students still find some difficulties related to the complexity of English vocabularies and the different pattern or grammar between Bahasa Indonesia and English (Nurhanifah \& Widayati, 2012). Thus, it is a challenging for the English teachers to teach English smoothly in order to make the students understand and comprehend English.

Since English plays important role as a tool for world communication (Chang, 2011), it is worth for the English teachers to make the students understand and comprehend English by teaching English through the easiest ways, and one of them is through code mixing (Pamungkas, 2008). According to Pamungkas (2008), it is something natural when the teachers use code mixing between English-Bahasa Indonesia, because the teachers and students are Indonesian people, so Bahasa Indonesia is the mother tongue for most Indonesian students. The phenomenon of code-mixing is frequently practiced.

According to Sumintono et al. (2012), throughout the lessons, most of the English teachers mix English with Bahasa Indonesia to explain subject matter, to ask questions, and for giving examples. The use of code mixing in language teaching especially English, cannot be interpreted as the English teachers' inability to use English well, but they use code mixing in case of needs (Lu, 2014).

The same case can be found in SMAN Bali Mandara. The English teacher in SMAN Bali Mandara still find some difficulties to teach using full English in the whole teaching and learning process, although the school applies the policy of using only English in the teaching and learning activities. From the preliminary interview, the use of code mixing is frequently needed by the English teacher in teaching some English skills. Although the school tells to use full English, but the teacher said that code mixing is needed to teach English in the teaching and learning process.

Based on that phenomena, where code mixing is needed in teaching English, it is interesting for the researcher to conduct this study about the use of code mixing by the English teacher in SMAN Bali Mandara to find out the processes of code mixing used by the English teacher in the verbal sentences during teaching-learning process and the reasons why code mixing is needed in teaching English. It was also done to give clear responses from the students about the use of code mixing used by their English teacher.

\section{METHOD}

The design used in this research was descriptive qualitative, which Zuriah 
(2006: 92) defines as procedure research that result a descriptive data which is written words or saying words from people whom can be observed. Meanwhile, Arikunto in Danial (2009) defines descriptive research is research which intend to collect information about anything that happen in that place according to the naturalistic occasion. Here, the researcher came to the school as a non-participant researcher to observe directly and then take the data from recording through the naturalistic occasion in teaching-learning process.

This study conducted in SMAN Bali Mandara during teaching and learning process on English subject. The subject was the English teacher, who taught English in SMAN Bali Mandara at $10^{\text {th }}$ grade and using code mixing while she was teaching English in the classroom. The objects of study were the processes of code mixing used by the English teachers in SMAN Bali Mandara, the English teachers' reasons of using code mixing in the teaching and learning process and also the students' responses, who were taught by the teacher using code mixing. Several instruments were used in this study based on the problems of the study. The key instrument of this research was the researcher, because the researcher was the one who determines whether this research was continued or not. Besides, the data in this study were gained from supporting instruments, namely: observation sheet, mobile phone, interview guide, and questionnaire.

Observation sheet was used to answer the first research problem that was the processes of code mixing used by the English teacher at SMAN Bali Mandara. Then, mobile phone which was used as audio recorder was also answer the first research problem as stated previously. Meanwhile, interview guide was helping the researcher when interviewed the English teacher who taught using code mixing. After that, the data for the last research problem was gained using questionnaires which were distributed for the students who was taught using code mixing.

In this study, the data analysis was organized into four steps. Firstly, the researcher collected all data by observing and recording the teaching and learning process. Then, the audio recording was transcribed into written form. Secondly, the data reduction was needed by selecting the essential information that was used as the essential data. In this case, the data of code mixing are listed and classified on classification framework by Muysken (2000) namely, insertion, alternation and congruent lexicalization. Thirdly, after reducing the data, it was displayed in the form of conversation transcription and table. The researcher was analyzing the data recorded and listing all the sentences produced by teacher in the classroom. Fourthly, the data display and analysis were used as the basis for further discussion on the findings. The verification process included the researcher's interpretation on the code mixing produced by the English teacher based on the Muysken's (2000) classification.

\section{FINDINGS \& DISCUSSIONS}

Answering the first research problem that was the processes of code mixing used by the English teacher at SMAN Bali Mandara, it was found that there were 117 items of code-mixing used by the English teacher at SMAN Bali Mandara during the observation. Based on Muysken's (2000) classification framework there were three processes of code mixing used by the English teacher in the observation and recording as follows: (1) eighty four (62.22\%) items of Insertion, (2) thirty seven $(27.41 \%)$ items of Alternation, and (3) fourteen (10.37\%) items of Congruent Lexicalization. The finding on the processes of code mixing used by the English teacher of grade $X$ at SMAN Bali Mandara is summarized in Table 1.

Table 1. Processes of process of code mixing

\begin{tabular}{rcrr}
\hline $\begin{array}{c}\text { Proces } \\
\text { ses of Code } \\
\text { Mixing }\end{array}$ & $\begin{array}{c}\text { N } \\
\text { umber } \\
\text { of } \\
\text { Mixing } \\
\text { Code }\end{array}$ & $\begin{array}{r}\text { Perce } \\
\text { ntage (\%) }\end{array}$ \\
Insertio & 84 & 62.22 \\
\hline
\end{tabular}




\begin{tabular}{lllll}
\hline $\mathrm{n}$ & Alternat & 37 & $\%$ & 27.41 \\
ion & Congru & 14 & $\%$ & 10.37 \\
ent & & & $\%$ & \\
Lexicalization & & & \\
\hline
\end{tabular}

The findings of insertion in the English teacher' sentences at SMAN Bali Mandara were similar to the result of the research conducted by Pambudhi (2012). Indonesian words or phrases were inserted in the English sentences. It is in line with Muysken (2000) which told that when single constituent in form of word or phrase is mixed, insertion is plausible option. However, the findings of alternation English teacher' sentences in this research are similar to the result of the research conducted by Pambudhi (2012).Indonesian structure was mixedwith English utterance. It is regarding to the theory stated by Muysken (2000) which told that the words in English is mixed with words in Bahasa Indonesia, but both of them has their own structure in a sentence or utterance. Meanwhile, congruent lexicalization sentences produced by the English teacher at SMAN Bali Mandara were similar to the result of the research conducted by Pambudhi (2012). Words, phrases and clauses in Bahasa Indonesia were mixingwith English utterance. It is in line with the theory stated by Muysken (2000) which told that the words in English is mixed with words in Bahasa Indonesia, but both of them has their own structure in a sentence/utterance.

The next finding is about the English teacher' reasons using code mixing in the teaching and learning process. Based on the interviewed did by the researcher, it was found that there were five reasons why the English teacher at SMAN Bali Mandara used code mixing. The first reason was to help the students to comprehend the learning material. This is related to Hoffmann (1991) stated the intention of clarifying the speech content or interlocutor. It sometimes allows people mixed from one language to another hoping that the other person will understand what $\mathrm{s}(\mathrm{he})$ talks about. So the teacher uses code mixing in order to deliver the message and to make it easier for the students to catch the point of the material taught by the teacher.

Then, the second reason was to help the teacher to give instruction and tell the rules to the students. It is in line with Hoffmann' (1991) theory which stated that code mixing can be use for clarifying the speech content for interlocutor. Sometimes when the teacher gives instruction to the students to do some class activity, code mixing will be used to avoid wasting time. It is also related with Hoffman' (1991) theory that is being more emphatic about something. So, the teacher uses code mixing to be more emphatic with the rules on each activities that should be obeyed by the students.

Afterward, the third reason of using code mixing was to help the teacher teaches vocabulary mastery to the students. It is in line with Napitupulu (2010:20) that is the lack of vocabulary in a language or there is no appropriate word in a language. In order to define certain English words, the teacher prefers to use the students' native language to define some vocabularies.

Next, the fourth reason of using code mixing was to help the teacher to make the learning environment become comfortable for the students. It is related with Napitupulu (2010:20), that is code mixing can create relax situation in the teaching and learning process. It is because the students' habitual sentences are used by their teacher. So, the teacher also will be more helpful while teaching the students because they are happy in their learning process.

Finally, the last reason was to help the teacher when giving jokes or idioms. It is in line with Hoffman (1991) that is people sometimes like to use famous expression or well-known figure. Even the jokes or idioms are coming from the English native's culture, the teacher still want to make those jokes/idioms become familiar for the students. So, the teacher tries to relate those idioms or jokes with Indonesian' culture to make it seems like exist around the students' environment and culture.

Based on the questionnaires which were distributed to the students taught using code mixing, it was found that the 
students' responses on the use of code mixing by their English teacher were different. There were $12.96 \%$ responses from the students that prefer to be taught using full Bahasa Indonesia. It is because they think that English is complicated subject that must be studied and they could not understand what their teacher said when teaching using full English. Then, there were $28.33 \%$ responses from the students that prefer to be taught using full English. It is because they want to know how to pronounce some vocabularies in right way and they want to practice their English as well. However, there were $58.70 \%$ responses from the students that prefer to be taught using code mixing of English-Bahasa Indonesia. There are many reasons why they said so, because (1) they are more understand with the content of the English material itself, (2) they can know many vocabularies if English vocabularies are defined into Bahasa Indonesia, (3) they can master the structure of English (grammar), and (4) they can feel secure and free to ask when the their teacher using code mixing English-Bahasa Indonesia.

The first, second, and third reasons were related to Chit Yi (1999) which states that the use of code mixing will facilitate the students in the aspects of the content of English material, vocabulary mastery, and grammar mastery. Meanwhile, the fourth response was in line with Chit Yi (1999) which states that the use of code mixing is able to negotiate social rules in some aspects such as make the relationship between teacher and students become less formal in terms of teaching-learning process, and increase communicative interaction between teacher and the students.

\section{CONCLUSION AND SUGGESTION}

Since code mixing is needed by the English teacher at SMAN Bali Mandara, this study is properly conducted in this school. Based on the data gotten by the researcher, it can be concluded that in the process of code mixing produced by the English teacher, there are 84 sentences (62.22\%) classified as insertion, and then 37 sentences (27.41\%) belongs to alternation, and the last there are 14 sentences $(10.37 \%)$ classified as congruent lexicalization. However, there are five reasons why the English teacher use code mixing, (1)The first reason is intention of clarifying the speech content for interlocutor, (2) The second reason is being emphatic about something, (3) The third reason is there is no appropriate word which can be understood by the students, (4) The fourth reason of using code mixing is to help the teacher to create relax situation, (5) The last reason is quoting somebody else. Meanwhile, as the feedback of the use of code mixing, the responses from the students were quietly good. From the result of questionnaire which were distributed to the students who were taught using code mixing, here are the students' responses about the use of code mixing used by their teacher, (1) code mixing is able to facilitate the students in some aspects such as the content of English material, vocabulary mastery, and grammar mastery, and (2) code mixing is able to negotiate social rules in some aspects such as make the relationship between teacher and students become less formal in terms of teaching-learning process, and increase communicative interaction between teacher and the students.

With the regard to the above phenomena, it is suggested for the English teacher to use code mixing in the teaching and learning process, because the use of code mixing will not interpret an English teacher that she he has low proficiency in English, but because the students really need it. Just because an English teacher is fluent to speak English, has high level grammar mastery and plentiful of English vocabulary, but those are do not guarantee that you are a good teacher for your students and you have high achieving students. A teacher should make a strong relationship with the students to build a communicative interaction in the teachinglearning process. All in all, it is suggested for the English teacher to consider this suggestion, but still depend on the characteristics of the students and the need of use it. 


\section{REFERENCES}

Berthele, Raphael. 2012. "The influence of code-mixing and speaker information on perception and assessment of foreign language proficiency: An experimental study". International Journal of Bilingualism, Volume 16, No. 4, (p. 1). Available at http://doc.rero.ch/record/31421/files/bert hele_ijb_mixing 429514_final_rerodoc. pdf (accessed on $30^{\text {th }}$ January 2015)

Cakrawarti, Dias. 2011. Analysis of Code Switching And Code Mixing In The Teenlit Canting Cantiq By Dyan Nuranindya. An Undergraduate Thesis. Semarang: Faculty of Humanities Diponegoro University

Chaer, Abdul \& Leonie Agustina. 2004. Sosiolinguistik. Jakarta: PT Rineka Cipta.

Chang, B-M. 2011. "The roles of English language education in Asian context". Journal of Pan-Pacific Association of Applied Linguistics, Vol. 15(1), (p.191206).

Chit Yi, Lam. 1999. The Use of Mixed Code in F.1 Language Classes In Hong Kong CMI and EMI Schools. A Postgraduate Thesis. Hong Kong: University of Hong Kong. Available at http://hub.hku.hk/handle/10722/28830;js essionid=C6AFE73B6D8126237BA702

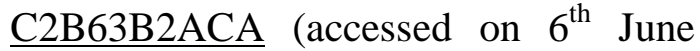
2015)

Corder, S.Pit. 1973. Introducing Applied Linguistic. Great Britain: Penguin Books.
Debora, Flora. 2014. "Learning Content Subject Through English: Indonesian High School Students' Voices". In The New English Teacher 7.1 (p. 30-45). Assumption University of Thailand. Available at https://www.academia. edu/4525486/Learning_Content_Subject s_through_English_Indonesian_High_S chool_Students_Voices (accessed on 30th January 2015)

Ehsan, Andleeb, et.al. 2014. "Code-Mixing In Urdu News of A Private Pakistani Channel: A Case Study". Academic Research International, Vol. 5, No. 1. Available at www.journals.savap.org.pk (accessed on $30^{\text {th }}$ January 2015)

Gunawan, I Putu. 2013. An Analysis of Code Mixing Used By Lecturers and Students of Darmasiswa Program In Ganesha University of Education. An Undergraduate Thesis (Unpublished). English Education Department, Undiksha University of Education Singaraja.

Ho, Judy Woon Yee. 2007. "Code-mixing: Linguistic Form and Socio-Cultural Meaning". The International Journal of Language Society and Culture, Vol. 21.Available at www.educ.utas.edu.au/users/tle/JOURN $\underline{\mathrm{AL} /}$ (accessed on $20^{\text {th }}$ January 2015)

Hoffman, Charlotte. 1991. An Introduction to Bilingualism. London: Longman.

Holmes, Janet. 1992. An Introduction to Sociolinguistics. New York: Addison Wesley Longman, Inc. 
Miles, Matthew B. \& A. Michael Huberman. 2009. Analisis Data Kualitatif. Jakarta: Universitas Indonesia.

Jendra, Made Iwan Indrawan. 2012. Sociolinguistics: The Study of Societies' Languages. Yogyakarta: Graha Ilmu.

Kia, Lau S. 2011. "Code-Mixing of English in the Entertainment News of Chinese Newspapers in Malaysia”.International Journal of English Linguistics.Vol. 1, No. 1. Available at www.ccsenet.org/ijel (accessed on $30^{\text {th }}$ January 2015)

Lu, Dan. 2014. "Code-Mixing and Its Impact On Language Competence". International Journal of Language Studies, Volume 8, Number 2 (pp. 7590).

Available at https://www.academia.edu/8131107/Cod emixing_and_its_impact_on_language_c ompetence (accessed on $25^{\text {th }}$ January 2015)

McKay, S.L. \& Nancy H. Hornberger. 2009. Sociolinguistics and Language Teaching $13^{\text {th }}$ Printing. Cambridge: Cambridge University Press

Muysken, Pieter. 2001. Bilingual Speech: A Typology of Code Mixing". Cambridge University Press. Available at http://catdir.loc.gov/catdir/samples/cam0 32/99056423.pdf(accessed on $20^{\text {th }}$ January 2015)

Napitupulu, Sependi. 2010. Code Mixing and Code Switching Used by The Presenters on RRI Station Medan. A
Postgraduate Thesis.University of

Medan.Available at

http://digilib.unimed.ac.id/code-mixing-

and-code-switching-used-by-the-

presenters-on-rri-station-medan-

1272. html. (Accessed on $10^{\text {th }}$ June 2015)

Nababan, P.W.J. 1991. Sosiolinguistik : Suatu Pengantar. Jakarta: PT. Gramedia

Nadeem, Mubashar. 2012. "Urlish: A Code Switching/Code Mixing Pedagogical Approach in Teacher Education". Journal of Research and Reflections in Education, Vol.6, No.2 (pp154 -162).

Nugraha, I Ketut. 2014. Indonesian-English Code Mixing Used By Characters In Films Written By Raditya Dika. An Undergraduate Thesis (Unpublished). English Education Department, Ganesha University of Education Singaraja.

Nurhanifah, Devi \& Sri Widayati. 2012. "The Problems Of Second Grade StudentsOf SMPN 4 Malang In Learning English And The EffortsMade To Overcome Them". Available at http://jurnalonline.um.ac.id/data/artikel/ artikel73D5F26D76B9CC591DB29FB5 12B20360.pdf. (accessed on $10^{\text {th }}$ June 2015)

Pamungkas, Putri. 2008. The Study of Code Mixing in Teaching Learning Processof Speaking in English Departmentof Ums 2007/2008. An Undergraduate Thesis.School of Teacher Training and EducationMuhammadiyah, University Of Surakarta. Available at http://eprints.ums.ac.id/3690/ (accessed on $29^{\text {th }}$ Mei 2015) 
Purba, Sri Maharani. 2009. Code-Mixing Used In Gogirl Magazine. A paper for Diploma (D-III) in English Department of North Sumatera University. Available at

http://repository.usu.ac.id/xmlui/handle/ 123456789/17294? show=full (accessed on $25^{\text {th }}$ January 2015)

Pambudhi, Pandu. 2012. The Analysis of Code Switching and Code Mixing In Reading V Class of English Department of Purworejo Muhammadiyah University In The Academic Year 2011/2012. An Undergraduate Thesis.English Education Department of Muhammadiyah University of Purworejo. Available http://www.4shared.com/office/OtbCXq 4jba/Pandu_Pambudi_3_html (accessed on $2^{\text {th }}$ June 2015)

Pramudya, Ageng, et.al. 2013. "An Analysis Study of Code-Mixing and CodeSwitching Used by Mathematics Teachers". Available at http://ejournal.unpak.ac.id/download.ph $\mathrm{p}$ ?file $=$ mahasiswa $\& \mathrm{id}=667 \&$ name $=$ Jour nal\%20Ageng\%20TP\%20031108040).p df (accessed on 30 ${ }^{\text {th }}$ January 2015)

Ronald, Wardaugh. 2002. An Introduction to Sociolinguistics, $4^{\text {th }}$ Edition. Oxford : Blackwell Publishing.

Saputro, Ari. 2013. The Analysis of Indonesian-English Codes Mixing Used In "Marmut Merah Jambu" Novel. Undergraduate Thesis. Salatiga: English Department of Education Faculty State Institute of Islamic Studies (Stain).
Sumarsih, et.al. (2014). "Code Switching and Code Mixing in Indonesia: Study in Sociolinguistics". English Language and Literature Studies, Volume 4, No. 1. Available at http://dx.doi.org/10.5539/ells.v4n1p77 (accessed on $25^{\text {th }}$ January 2015)

Sumintono, Bambang, et.al. 2012. Too Difficult To Reach: A Case Study of The Implementation of Teaching-Learning With English In Indonesia's International Standard Schools. In: Educational Issues, Research and Policies. Available at http://eprints.utm.my/27805/ (accessed on $25^{\text {th }}$ January 2015) 